https://helda.helsinki.fi

\title{
Democracy both Young and Old : Finland, Sweden and the Interwar Crisis of Democracy
}

Kurunmäki, Jussi

2019

Kurunmäki , J 2019 , ' Democracy both Young and Old : Finland, Sweden and the Interwar

Crisis of Democracy ' , Journal of Modern European History , vol. 17 , no. 4 , pp. 486-499 . https://doi.org/10.1177/16

http://hdl.handle.net/10138/325676

https://doi.org/10.1177/1611894419880461

cc_by_nc_nd

acceptedVersion

Downloaded from Helda, University of Helsinki institutional repository.

This is an electronic reprint of the original article.

This reprint may differ from the original in pagination and typographic detail.

Please cite the original version. 
Democracy both Young and Old

Finland and Sweden and the Interwar Crisis of Democracy

Jussi Kurunmäki

The new independent states born of World War I, with their democratic constitutions, turned out to be fragile in the face of autocratic and totalitarian doctrines and practices. Only Finland and Czechoslovakia managed to maintain their democratic constitution and parliamentary institutions more or less intact during the interwar years. ${ }^{1}$ It is therefore understandable that, in the literature on the interwar crisis of democracy, much attention has been paid to how well the political systems were historically grounded, especially in order to explain the sustainability and fragility of democracy. The argument generally advanced is that those countries which had been democratic for a longer time and were marked by continuity of their political institutions were better able to stand against totalitarian and autocratic political forces. Robert A. Dahl, for instance, has held that the surviving democracies of the 20th century were 'precisely the countries we can now call the older democracies'. ${ }^{2}$ In a similar vein, Samuel P. Huntington pointed out that newly

1 See, e.g., G. Capoccia, Defending Democracy. Reactions to Extremism in Interwar Europe, Baltimore, London 2005, 6-9. 2 R. A. Dahl, On Democracy, New Haven, London 2000, 157. 
introduced democracies failed in the interwar years in those countries that 'had adopted democratic forms just before or after World War I, where not only democracy was new but also, in many cases, the nation was new' ${ }^{3}$

The distinction between old and young democracies in this kind of study is based on an analytical definition of what makes a regime a democracy. Such a definition usually leans on an evaluation of social structures, continuity of political institutions, and a gradual inclusion of social classes into political citizenship. Some seminal studies have also emphasised the importance of political culture and the legitimacy of political systems. Seymour Martin Lipset, for

3 S.P. Huntington, The Third Wave: Democratization in the Late Twentieth Century, Norman, OK 1991, 17. For rather similar argument, see, e.g., D. Berg-Schlosser, 'Conditions of Authoritarianism, Fascism and Democracy in Inter-War Europe: A Cross-Sectional and Longitudinal Analysis', in: International Journal of Comparative Sociology 39 (1998) 4, 335-377, 339340; idem, 'Long Waves and Conjunctures of Demoratization', in: C.W. Haerpfer et al. (eds.), Democratization, Oxford 2009, 41-54, 47; R. Bessel, 'The Crisis of Modern Democracy, 191945', in: D. Potter et al. (eds.), Democratization, Cambridge 1997, 71-94, 90-92; A. Cornell / J. Møller / S.-E. Skaaning, 'The Real Lessons of the Interwar Years', in: Journal of Democracy 28 (2017) 3, 14-28, 15. 
instance, maintained that a high level of legitimacy was crucial for those countries that remained democratic in the 1930s. ${ }^{4}$ However, these studies have not paid much attention to the ways in which the people and their political leaders themselves expressed their view of democracy. ${ }^{5}$ This study will historicise the notions of old and young democracy by investigating the ways in which Finland was rhetorically forged into an old democracy. In order to do so, we must also understand the ways in which Sweden became understood as an old democracy. Finland had been an integrated part of the Swedish kingdom for more than six centuries before it became a grand duchy within the Russian empire in 1809. The Swedish constitutional and legal tradition had been a crucial component of political identification among the Finns who sought to construct an autonomous status for the grand duchy. While Finland fits in the analytical category of new

4 S.M. Lipset, 'Some Social Requisites of Democracy: Economic Development and Political Legitimacy', in: The American Political Science Review 53 (1959) 1, 69-105, 87-90; see also J.J. Linz, The Breakdown of Democratic Regimes. Crisis, Breakdown, \& Reequilibration, Baltimore, London 1978, 45. 5 J. Kurunmäki, 'The Lost Language of Democracy. Antirhetorical Traits in Research on Democratisation and the Interwar Crisis of Democracy', in: Res Publica: Revista de filosofía política 15 (2012) 27, 121-130. 
democracies, Sweden makes a good example of an old democracy by the same standards. Finland became an independent state in 1917, experienced a civil war in 1918, and had adopted a republican democratic constitution in 1919, which was challenged by the extremist right-wing Lapua Movement in the early 1930s. The defence of democracy against the movement has made the country a notable case in the literature on the interwar crisis of democracy. ${ }^{6}$ Sweden is an old state with a long constitutional tradition and a gradual democratisation of political representation. The principle of parliamentary government was implemented in 1917 and universal suffrage was decided upon in 1918. Sweden is regarded as a prime example of a country where the transnational crisis of democracy never really had an impact as a consequence of Social Democratic policies of reformism and compromise. ${ }^{7}$

6 R. Alapuro / E. Allardt, 'The Lapua Movement. The Threat of Rightist Takeover in Finland, 1930-1932', in: J. J. Linz / A. Stepan (eds.), The Breakdown of Democratic Regimes. Europe, Baltimore, London 1978, 122-141; Capoccia, Defending Democracy, $138-176$.

7 See, e.g., M. Hilson, 'Scandinavia', in: R. Gerwarth (ed.), Twisted Paths. Europe 1914-1954, Oxford 2007, 20-31; T. Ertman, 'Democracy and Dictatorship in Interwar Western Europe Revisited', in: World Politics, 50 (1998) 3, 475-505; S. 
In what follows, this article first discusses how Finland was thought of as a young or a new democracy, after which it focuses on the ways in which Finland and Sweden have been described as old democracies. The analysis will thereafter investigate how the age of democracy was used as an argument in the defence of democracy in the international crisis of democracy in the 1930s. As will be shown, the rhetoric of 'Nordic democracy' was a crucial part of that argument. The analysis will be connected to Karl Loewenstein's discussion on the fragility of democracy, in which he pointed to the Nordic countries as examples of the old democracies that had been able to defend democracy in the time of crisis.

\section{Finland as a young democracy}

Expressions such as 'our young democracy' began to appear in Finnish newspapers in 1905 after a general strike that took place in the context of a sudden weakness of the imperial Russian government, caused by its lost war against Japan. 8 The

Berman, The Primacy of Politics. Social Democracy and the Making of Europe's Twentieth Century, Cambridge 2006, 152-176. 8 See, e.g., Helsingfors Posten, 19 December 1905; Wasabladet, 11 April 1907; Nya Pressen 23 May 1908. This and the following observations are based on the search for 'young democracy' (nuori demokratia) and 'new democracy' (uusi demokratia) in the digitalised corpus of Finnish newspapers in the Finnish 
window of opportunity led to the 1906 parliamentary reform in Finland, in which equal and universal suffrage was granted to both men and women. ${ }^{9}$ When the Diet debated the bill in 1906 , it was held that a new era for Finland was beginning. ${ }^{10}$ Democracy was discussed in Finland both in Finnish and in Swedish, as the Swedish language had been the main language of political debate, administration and higher education until the late 19th century, although the vast majority of the people had Finnish as their native language. ${ }^{11}$ The difference between languages had some important consequences for the ways in which democracy was understood. While the Swedish words

National Library at

https://digi.kansalliskirjasto.fi/sanomalehti/ (accessed 14 January 2018)

9 For the 1906 parliamentary reform, see J. Mylly, Edustuksellisen kansanvallan läpimurto. Suomen Eduskunta 100 vuotta 1, Helsinki 2006 .

10 J. Kurunmäki, 'The Breakthrough of Universal Suffrage in Finland, 1905-1906', in: K. Palonen / T. Pulkkinen / J. M. Rosales (eds.), Ashgate Research Companion to the Politics of Democratisation in Europe: Concepts and Histories, Farnham $2008,355-370,364-367$.

11 In 1880, ca. 15 percent of the people had Swedish as their native language. See M. Engman, Språkfrågan. Finlandssvenskhetens uppkomst 1812-1922, Helsingfors 2016, 33. 
demokrati and Finnish demokratia do not differ from the word used in other major languages, the Finnish word kansanvalta (people's power, rule of the people) also connoted the concept of nation, as kansa (the people, people) was also the root word of the term kansakunta (nation). Both aspects of the concept, the sovereign people and the national people, are always to some extent present in the concept of democracy, ${ }^{12}$ but in the case of kansanvalta the semantic closeness of the 'people' and 'nation' made both the radical democratic (power of the people) and the nationalist (power of the nation) connotations of 'democracy' quite apparent. The two sides of democracy were notably present in 1906 and especially in 1917, when Finland was noted as 'a young democracy' after the collapse of the tsarist regime in Russia in March 1917.13 As Pasi Ihalainen has shown, the term 'democracy' was more extensively used in Finland than in Sweden, Germany and Britain. ${ }^{14}$ All political parties referred

12 See B. Yack, 'Popular Sovereignty and Nationalism', in: Political Theory 29 (2001) 4, 517-536.

13 See, e.g., Åbo Underrättelser, 14 April 1917; Uusi Suometar, 1 May 1917.

14 P. Ihalainen, The Springs of Democracy. National and Transnational Debates on Constitutional Reform in the British, German, Swedish and Finnish Parliaments, 1917-1919, Helsinki 2017,278 . 
to the concept, but it was interpreted in highly contradictory ways, ranging from a proletarian view of democracy to a conservative nationalist view of the people as an idealised symbol of the nation. ${ }^{15}$ The already tense situation worsened dramatically during the Russian Bolshevik revolution in November, paving the way for the Finnish civil war in 1918. Both sides of the war - 'the Reds' and 'the Whites' - argued for their cause by referring to the defence of the young democracy in Finland. ${ }^{16}$

Even the political contest over the question of whether Finland would become a monarchy or a republic, debated in 1918/1919, was to a large extent conducted as a question of democracy. When the monarchists lost the case as a consequence of the collapse of the Wilhelmine regime in Germany, their argument for a 'monarchical democracy' was further developed into an argument for a politically powerful president. ${ }^{17}$ The Bolshevik revolution in Russia and its repercussions in

15 E.g. Sosialidemokraatti, 14 July 1917; Uusi Päivä, 12 June 1917

16 Suomen Kansanvaltuuskunnan Tiedonantaja, 23 February 1918; Valkoinen Suomi, 20 March 1918.

17 For a monarchical democracy, see Karjala, 31 July 1918. For monarchist views in general and the conservative adaptation to presidential democracy, see Ihalainen, The Springs of Democracy, 329, 500 . 
Finland had made many conservatives and even some former liberal or centrist advocates of kansanvalta critical of democracy. The critique of democracy was particularly notable among the principal party of the Swedish-speaking population, the Swedish People's Party. ${ }^{18}$

Consequently, a positive evaluation of democracy took on a republican and agrarian character in 'the White Republic'. ${ }^{19}$ Only the Progressive Party (Liberals) and the Agrarian Party mentioned 'democracy' in their party programmes in the $1920 \mathrm{~s} .{ }^{20}$ The Social Democrats, for their part, had an urgent need to show that they were distancing themselves from their former leadership, which had escaped to Soviet Russia and formed the Finnish Communist Party in Moscow. Quoting Karl Kautsky, they took a stand in favour of parliamentary democracy and against

18 See Ihalainen, The Springs of Democracy, 485-488.

19 Ilkka, 7 January 1920. For an example of republican support of democracy, see Turun Sanomat, 19 April 1921. For an Agrarian view, see Karjalan Maa, 27 May 1919. For the monarchists' positive use of 'new democracy' in Finland, see Karjala, 31 July 1918.

20 The Finnish party programmes are archived at http://www.fsd.uta.fi/pohtiva/ohjelmalistat (accessed 30 November 2017). 
dictatorship. ${ }^{21}$ As one of the party's magazines put it, 'it was possible to gain quite considerable victories in the workers' class struggle through democratic means'. ${ }^{22}$ However, it was difficult for them to convince the non-socialist side, not least because of groups such as the Social Democratic Youth, who in their journal criticised the use of such words as 'democrat' and 'social democrat' while claiming instead to be 'socialists'. 23

The expressions 'new democracy' and 'young democracy' sometimes appeared in Finnish newspapers as something that demanded an adaptation, the argument being that the extant new republic should be developed into a new democracy. ${ }^{24}$ It is also possible to find some clearly pejorative uses of the expression, in which reference was made to the political situation in the Soviet Russia and its political advocates in

21 See, e.g., Työn Valta, 31 May 1918; Suomen Sosialidemokraatti, 7 October 1918 and 28 October 1918 . 22 R. Itkonen, 'Kansanvallan vakiinnutaminen ja kunnallinen toiminta', in: E. J. Kotiranta (ed.), Punainen Viesti XIV. Sos.-Dem. Kevätjulkaisu v. 1921, Turku 1921, 8-10, 8. 23 Sapiens [pseudonym], Sosialisti - Sosialidemokraatti Demokraatti', in: Sosialistinen Aikakauslehti 1 (1919) 1, 7-8. 24 E.g. Savon Sanomat, 12 February 1920; Turun Sanomat, 19 April 1921 . 
Finland and elsewhere. ${ }^{25}$ Such terminology also had a wider resonance outside of Finland. In the aftermath of the collapse of authoritarian regimes at the end of the war, it was widely held that 'the young democracies' needed support and guidance, because the 'youngsters in democracy', as one US newspaper put it, were fragile and experienced 'explosive young diseases'.26 Importantly, this increased attention to the problems experienced by 'young democracies' briefly made the notion of 'old democracies' more common than before, as old constitutional states were re-described as democracies. ${ }^{27}$ The USA was regarded not only as the leader of the 'young democracies', ${ }^{28}$ but now also an 'old democracy' together with countries such as Britain, France and Italy. ${ }^{29}$ Hjalmar Branting, the leader of the Swedish Social Democrats and a

25 E.g., Uusi Suomi, 31 July 1921; Vaasa, 5 April 1927. 26 The Saturday Evening Post 191 (1919) 28.

27 This observation is based on a search of the English language dataset at the Google Books, see

https://books.google.com/ngrams/graph (accessed 5 January $2018)$

28 The Literary Digest 51 (1915), 1343.

29 See, e.g., Harvard Alumni Bulletin 21 (1918-1919), 325; The Delta of Sigma Nu fraternity 36 (1919), 182. For Finnish notions of USA as the guide and support for young democracies, see Uusi Päivä, 13 December 1918; Aamulehti, 14 December 1918. 
prominent advocate of the League of Nations, envisaged a peacetime Europe as the Europe of 'old democracy and socialism'. ${ }^{30}$ Finnish Foreign Minister Rudolf Holsti (Liberals) for his part maintained that revolutionary ideas had emerged especially in those countries where conservatism had ruled, whereas the workers had shown a more mature and reformist stand in the old democratic states. In such a categorisation, Finland belonged, obviously, to the former group. ${ }^{31}$ The use of the term 'young democracies' became less common towards the end of the 1920s. ${ }^{32}$ Although it might have been thought that this was because young democracies had grown older, it is more important to view the decline of the term as a sign of a general critique of democracy. ${ }^{33}$ In 1923, a

\footnotetext{
30 Hufvustadsbladet, 14 January 1920.

31 Helsingin Sanomat, 8 February 1920; Dagens Press, 9 February
} 1920.

32 This observation is based on a search of the archive of Finnish newspapers at the Finnish National Library at https://digi.kansalliskirjasto.fi/sanomalehti/ (accessed 14 January 2018) as well as of the English language corpus at Google Books at https://books.google.com/ngrams/graph (accessed 5 January 2018). 33 See, e.g., M. Mazower, Dark Continent. Europe's Twentieth Century, London 1998, 8-39; F. Stern, 'The New Democracies in 
conservative Finnish newspaper pointed out the fragility of young democracies because of the increased appeal that dictatorship had in these countries. According to the paper, this was especially the case in Germany, where the war had raised democracy to power, even though 'there were no democrats' in the country. ${ }^{34}$ Another conservative paper noted a couple of years later that respect for democratic institutions was higher in old democracies than in young ones. This message was directed to the Finnish Social Democrats who, according to the columnist, had been criticising parliamentary institutions in a manner that undermined their legitimacy. 35 However, it was more common in conservative argumentation to criticise parliamentary democracy than to defend it. ${ }^{36}$ The historian Jaakko Forsman, for instance, held that modern democracy was an ideology which in practice did not mean the power of the people, but, instead, the power of party leaders

Crisis in Interwar Europe', in: A. Hadenius (ed.), Democracy's Victory and Crisis, Cambridge 1997, 15-23.

34 Karjala, 4 October 1923.

35 Satakunnan Kansa, 15 July 1925.

36 See also A. Elmgren, 'Medborgerliga rättigheter? De intellektuella och 1930-talets statsmakt', in: H. Meinander / P. Karonen / K. Östberg (eds.), Demokratins drivkrafter. Kontext och särdrag i Finlands och Sveriges demokratier 18902020, Helsingfors, Stockholm 2018, 225-256, 226. 
who demagogically spoke in the name of the people. Quoting authorities such as Jean-Jacques Rousseau and Gustave Le Bon, and clearly drawing on Robert Michels and Carl Schmitt, he argued that the people could not be democratically represented. He also explained that it would have been easier for the Finns if they had used the Greek word demokratia instead of the Finnish word kansanvalta, because the foreign word would not have rendered so visible the contradiction that was built into the concept. ${ }^{37}$ While one conservative paper saw Forsman's article as 'a critique of the modern way of life', 38 the leading liberal paper criticised its monolithic view of the people and held that a vibrant civil society with its meetings and free press were proof of the opposite. ${ }^{39}$ There were two cleavages in Finnish political culture that kept the language of democracy somewhat central to political debates: the division of the civil war, which fuelled the dichotomy between democracy and communism; and the controversy between Finnish-language nationalists and the advocates of Swedish nationality in Finland, which made 'Finnish democracy' a label that was deployed on both sides of the language strife. It is striking that the Swedish-language press in

37 J. Forsman, 'Ideologia ja politiikka', Valvoja-Aika (1926) $7-8,249-260,250,255-256$.

38 Laatokka, 9 September 1926.

39 Helsingin Sanomat, 3 October 1926. 
Finland seems not to have had any positive description of finsk demokrati in the 1920s.40 Their critique of Finnish democracy was based not only on the conservatism of the leading advocates of the Swedish Party, but also on their view of the nature of Finnish-language culture. As one author put it, Swedish culture in Finland was the bearer of an eighthundred-year-old German political system that had fought against Russian unfreedom and violence, which he then set against 'the contemporary Finns' demands for levelling and the power of the masses'. ${ }^{41}$ It was also claimed that Finns were not able to support a civilised culture and that democracy was a proof of it, ${ }^{42}$ along with denunciations that 'democracy exists only for the Finns, but not for the Swedish part of our people'. ${ }^{43}$ Such rhetoric notwithstanding, it should nevertheless be noted that there were some notable leftist

40 This observation is based on the search for 'Finnish democracy' in Swedish (finsk demokrati) in the 1920s in the digitalised corpus of Finnish newspapers in the Finnish National Library at

https://digi.kansalliskirjasto.fi/sanomalehti/ (accessed 14 January 2018)

41 E. Schybergson, '1920', in: Hälsning till sydvästra Finlands svenska allmoge, Åbo 1920, 3-4, 4.

42 Vasabladet, 10 September 1922.

43 Vasabladet, 1 August 1923. 
intellectuals who belonged to the Swedish People's Party. Moreover, the party co-operated on several occasions with the Social Democrats, who had in general an open-minded view of the language issue. ${ }^{44}$

The language issue also dominated Finnish-language references to 'Finnish democracy'. In the rhetoric of the Agrarian Party, it was common to contrast suomalainen kansanvalta with the notion of the Swedish-speaking reactionary upper class. The party's nationalist-democratic rhetoric was often directed at the Social Democrats and the Communists, but it is noteworthy that the most vocal rhetoric of 'Finnish democracy' in Finnish was directed against the manifestations of 'Swedishness' in Finland. ${ }^{45}$ Close to the Agrarian Party, but nevertheless a cross-party language nationalist movement, the Pure-Finnish (aitosuomalainen) movement was significant in its attack on Swedish elitism in Finland, which was taken to oppose the democratic nature of Finnishness. ${ }^{46}$ In the rhetoric of the leading Pure-Finnish ideologists, Finnishness was the same as

44 See, H. Meinander, Nationalstaten. Finlands svenskhet 19222015, Helsingfors 2016, 21-23.

45 Ilkka, 10 March 1926. See also A. Elmgren, Den allrakäraste fienden. Svenska stereotypier i finländsk press 1918-1939, Lund 2008,68 .

46 E.g. Suomi, 22 October 1925; S. Kirri, 'Pakina Helsingistä', in: Aitosuomalainen 4 (1927) 50, 908-909. 
being democratic. ${ }^{47}$ In this way, the language nationalists on both the Finnish and Swedish sides of the linguistic dispute seemed to agree on the essentially democratic nature of the Finns. Moreover, the Finnish language nationalist rhetoric was not limited to attacking the advocates of Swedish language in Finland, but often also Sweden and Scandinavia. ${ }^{48}$

\section{A Democratic tradition in Sweden and in Finland}

While the young Finnish democracy was in many regards antiSwedish in character, the notions of an old democracy in Finland were to a large extent based on Sweden. In Sweden, the idea that there was an ancient age of democracy in Sweden, Scandinavia or Norden - the words were often used interchangeably - had appeared in the debates on noble privileges in the late 1760s (thus including most of the area that came to be Finland) and was established during the early 19th century, as the Viking-age peasant freedom and equal participation in local ting-assemblies was cherished in romantic literature and historiography. In the works of the

\footnotetext{
47 For the most explicit statement, see E. A. Aaltio, 'Suomalainen kansanvalta', in: Aitosuomalainen 4 (1927) 31-32, $563-567$

48 See, e.g., [anon.] 'Herra Erik Hornborgin katsaus', in: Aitosuomalainen 4 (1927) 27, 495-499, 498; Aitosuomalainen, 23 March 1929.
} 
historian Erik Gustaf Geijer, it was an anti-aristocratic idea at the same time as it was a monarchical one, emphasising a harmonious relationship between the peasants and their $\mathrm{king} \cdot{ }^{49}$ The notion was used as an argument in Swedish mid-19th-century political debates on the reform of estate-based political representation. It was employed both in favour of political reforms and against democratisation, as it was possible to maintain that the principles of the democratic past should be restored in a modern form, but it was also possible to claim that the existing tradition made further demands futile or even hazardous. ${ }^{50}$

In Finland, the notion of an ancient free peasantry and the coalition between the king and the peasants was discussed in a study of Swedish constitutional history by J.J. Nordström in 1839/1840. The topic was popularised by the famous journalist,

49 See, in particular, E. G. Geijer, 'Feodalism och republikanism', in: Samlade skrifter II, Stockholm 1874 [18181819], 270-379, 282. For an analysis, see J. Kurunmäki / I. Herrmann, 'Birthplaces of Democracy: The Rhetoric of Democratic Tradition in Switzerland and Sweden', in: J. Kurunmäki / J. Nevers / H. te Velde (eds.), Democracy in Modern Europe: A Conceptual History, New York, Oxford 2018, $88-112,95-98$ 50 See, e.g., Aftonbladet, 7 December 1843; Svenska Tidningen, 18 October 1852 . 
novelist, and history professor Zachris Topelius from the 1850s on. ${ }^{51}$ Both men were writing in the European intellectual context of the Romantic and Hegelian thinkers, and they were aware of the works of Geijer and his Swedish contemporaries, as they belonged to a Swedish intellectual sphere both in terms of learning and reputation. Unlike in Sweden, however, Finnish notions of the age of freedom were not turned to the rhetoric of democracy in the 19th century, but were increasingly interpreted as being focused on Finnish early medieval history in particular, rather than as part of a wider Swedish or Nordic heritage. ${ }^{52}$

The idea of the democratic past was used in both countries as a reformist rhetorical device when demands for parliamentary democratisation increased at the beginning of the 20 th

51 See M. Klinge, A History both Finnish and European. History and Culture of Historical Writing in Finland during the Imperial Period, Helsinki 2012, 84-91, 153-158, 186-193; M. Vuorinen, 'Herrat, hurrit ja ryssän kätyrit - suomalaisuuden vastakuvia', in: J. Pakkasvirta / P. Saukkonen (eds.), Nationalismit, Helsinki 2004, 246-264, 250-251.

52 See D. Fewster, 'Braves step Out of the Night of the Barrows'. Regenerating the Heritage of Early Medieval Finland', in: R. Evans / G. P. Marchal (eds.), The Uses of the Middle Ages in Modern European States. History, Nationhood and the Search for Origins, Basingstoke 2011, 31-51. 
century. In Sweden, the Liberals and the Social Democrats employed the idea of ancient democracy in their struggle for the parliamentarisation of the government and the democratisation of suffrage in the 1910s. In keeping with their critique of the bourgeois nature of the existing canon of Swedish history, the Social Democrats drew on the same historical symbols, but gave them their own reading. ${ }^{5}$ As Pasi Ihalainen has shown, many Social Democratic MPs referred to an ancient democratic tradition during parliamentary debates. ${ }^{54}$ The Liberals sought to historicise their demand for parliamentary government, which in some cases led to interpretations that drew on the idea of ancient democracy. This view gained support from the political scientist Fredrik Lagerroth, according to whom contemporary demands for parliamentarism were based on the oldest known organisation of

$53 \AA$ A. Linderborg, Socialdemokraterna skriver historia: Historieskrivning som ideologisk maktresurs, Stockholm 2001, $273,298-93$.

54 P. Ihalainen, 'The 18th-century Traditions of Representation in a New Age of Revolution', in: Scandinavian Journal of History 40 (2015) 1, 70-96, 73; Ihalainen, The Springs of Democracy, 161,171 
Swedish society, which was 'decisively democratic'.55 As the struggle over parliamentarism was directed primarily against the existing powers of the monarch, the leftist rhetoric of ancient democracy no longer emphasised the idea of the coalition between the monarch and the people.

In Finland, the Finnish-language nationalist spirit that characterised political life, whether in its conservative, liberal or socialist form, gave the Finnish trope of an ancient democracy a more diversified character than merely leftist. However, the socialists' rhetoric was in many regards similar to that in Sweden, as they viewed the Finnish tradition as belonging to the Swedish tradition, which was taken to have been originally democratic. The Nordic democratic past was used as an argument against the dual authority of the monarch and the parliament by Yrjö Sirola, the MP who came to be one of the leaders of 'the Reds', when in 1907 he claimed that 'in the times of the original Nordic democracy, the people had the right to elect and expel the king'.56 Likewise, some Social Democratic MPs held in 1917 that the Swedish tradition was originally democratic, but that the class interests of the Nobles, the Clergy and the bourgeoisie

55 F. Lagerroth, Frihetstidens författning. En studie i den svenska konstitutionalismens historia, Stockholm, 1915, 5-6, $280-81,322,385$ 56 Eteenpäin, 5 October 1907. 
had put an end to it. This socialist argument was also

developed into a Finnish nationalist interpretation, according to which the original Nordic democracy had existed in Finland before the country had come under Swedish rule. Importantly, there was also a non-socialist, mainly Agrarian, notion of a long tradition of the representation of free peasants, which was used as an argument in favour of democracy. For them, the language-nationalist popular movement was the bearer of that tradition. 57

Notwithstanding this kind of rhetoric, neither sweden nor Finland was commonly regarded as an old democracy in the 1920s. In Sweden, the Social Democrats argued for further democratisation in the name of 'industrial democracy' and 'economic democracy' ${ }^{58}$ The Liberals had lost much of the initiative, but were trying to compete with the idea of 'an enlightened democracy' in their electoral manifesto. ${ }^{9}$ The

57 Ihalainen, 'The 18th-century Traditions', 77-79, 84, 87; Ihalainen, The Springs of Democracy, 327; A.J. Alanen, Santeri Alkio, Porvoo 1976, 435 .

58 See A. Friberg, Demokrati bortom politiken. En begreppshistorisk analys av demokratibegreppet inom Sveriges socialdemokratiska arbetareparti 1919-1939, Stockholm 2012, $87-148$

59 The archive of the Swedish party programmes and manifestos at http://snd.gu.se/sv/vivill/party/ (accessed 7 March 2017). 
conservative parties preferred expressions such as 'ancient liberty', 'self-government' and 'popular rule' instead of 'democracy'.60 In the memoirs of the former US Ambassador to Sweden, Sweden was described both as a democratic and an aristocratic country, which had preserved its noble character even after democratisation, unlike many other countries that adhered to 'democratism'. The Swedish democracy was thus viewed as young and yet different from other new democracies because it was based, as it was held, on 'intellect's aristocracy' and 'an indifference between a nobleman and a peasant' ${ }^{61}$

The rhetoric of an old democratic tradition in Finland served purposes that were absent in Sweden. On the one hand, the civil-war background made it rhetorically appealing to use the idea of an old democratic past as an argument against current left-wing protests by claiming, as one conservative paper put it, that freedom, brotherhood, and equality had already been granted 'in our Nordic and original democratic society'. ${ }^{62}$ The conservative paper thus followed a pattern that had been established in Swedish conservative rhetoric in the 19th

60 See R. Torstendahl, Mellan nykonservatism och liberalism. Idébrytningar inom högern och bondepartierna 1918-1934, Stockholm 1969, 103 .

61 Svenska Dagbladet, 24 May 1923.

62 Iltalehti, 3 May 1924. 
century, when the trope of ancient Swedish democracy was used against political reforms. On the other hand, the idea of an old democratic past was used against the advocates of Swedishness in Finland. The argument was that Finland had originally formed part of the ancient democratic Nordic culture, but it had been destroyed by the Swedish colonialism in Finland. This pure-Finnish strand was based on the idea that 'Finnishness and democracy had almost always belonged together', as one of their main ideologists put it. ${ }^{63}$

\section{The fragility of democracy: from the crisis to Nordic democracy}

By the mid-1930s, a great deal of the negative attitudes towards Sweden in Finnish politics had relaxed, although the language issue was still a divisive political subject. However, it had taken a challenge to democracy in Finland, the rise to power of the Nazis in Germany, and the subsequent dissolution of the international order for this to happen. The change resulted in 'the Scandinavian orientation' of Finnish foreign policy, announced in 1935 and motivated by security

\footnotetext{
63 E. A. Aaltio, 'Suomalainen kansanvalta', in: Aitosuomalainen 4 (1927) 31-32, 563-567, 563. See also Helsingin Lehti, 18 August 1927; Maakansa, 19 August 1927.
} 
concerns. 64 The rapprochement had consequences with regard to how democracy was evaluated in Finland. For instance, the Finnish Conservative Party, which had previously been critical of democracy, linked the defence of 'the democratic and parliamentary constitution' with 'the inherited Nordic values and freedom' in its 1936 electoral manifesto. 65 Likewise, the Swedish People's Party welcomed the Scandinavian orientation by maintaining that the political system was based on the democratic ground in all these countries'.66

The Finnish crisis of democracy, in the form of the right-wing extremist Lapua Movement between 1929 and 1932, was in many ways similar to the attacks against democratic systems that were taking place in many other countries. Finnish newspapers usually compared it with Fascism in Italy, but references were

64 See L. Kaukiainen, 'From Reluctancy to Activity. Finland's Way to the Nordic Family during 1920 s and 1930s', in: Scandinavian Journal of History 9 (1984) 2, 201-219; J. Kurunmäki, 'Nordic Democracy' in 1935. On the Finnish and Swedish Rhetoric of Democracy', in: J. Kurunmäki / J. Strang (eds.), Rhetorics of Nordic Democracy, Helsinki 2010, 37-82, $52-65$

65 The archive of Finnish party programmes and manifestos at http://www.fsd.uta.fi/pohtiva/ohjelmalistat/ (accessed 30 November 2017). 66 Valtiopäivät 1935. Pöytäkirjat III, Helsinki 1936, 2518. 
also made to the National Socialists in Germany. ${ }^{67}$ Especially in its early phase, the movement had support from a wide range of non-leftist circles, including many industrialists and military officers as well as members of the non-socialist parties. The movement managed to have the political activities of the Communists banned. There were also plans to transform parliament into a corporatist chamber based on the representation of economic interests and to increase the power of the president. As the methods of the movement became increasingly violent, many centrist supporters distanced themselves from it. The movement was banned in 1932 after some of its leaders had demanded the resignation of the government by deploying armed men. At this stage, President Svinhufvud, a Conservative who had gained his position thanks to the Lapua Movement, stood against the leaders of the revolt and successfully upheld the rule of law in the country. The newly enacted 'communist laws' were used against the Lapua Movement itself; ${ }^{68}$ and, after the dissolution of the movement, right-

67 See R. Perälä, Lapuan liike ja sanan mahti, Rovaniemi 1998, 417.

68 See Capoccia, Defending Democracy, 6-9, 41-46; Alapuro / Allardt, 'The Lapua Movement', 122-141; J. Siltala, Lapuanliike ja kyyditykset 1930, Helsinki 1985; M. Uola, 'Parlamentaarisen demokratian haastajat 1920- ja 1930luvuilla', in: V. Vares / M. Uola / M. Majander (eds.), 
wing extremism found a new voice through the People's Patriotic Movement, which was based in the Conservative Party before it was thrown out of the party in 1934.69

The leaders of the Lapua movement claimed that they were defending democracy against Communism. ${ }^{70}$ This was a commonlyheld view: for example the leading Conservative paper held in 1929 that a temporary dictatorship could be needed in order to find 'strong personalities' and to guarantee the survival of democracy. ${ }^{71}$ Indeed, so widespread was the anti-Communist sentiment in the country that the Social Democrats' leader, Väinö Tanner, initially explained the emergence of the Lapua Movement as a reaction against the 'senseless and childish action of the Communists'. ${ }^{72}$ It was, nevertheless, more common

Kansanvalta koetuksella. Suomen Eduskunta 100 vuotta 3, Helsinki 2006, 190-246.

69 See Uola, 'Parlamentaarisen demokratian haastajat', 213-214, 250-254; V. Vares, 'Kokoomus ja demokratian kriisi', in: V. Vares / A. Uino, Suomalaiskansallinen Kokoomus. Kansallisen Kokoomuspuolueen historia 1929-1944, Helsinki 2007, 35-37, $106-107,118-119$.

70 See V. Vares, 'Kokoomus ja demokratian kriisi', 20; Siltala, Lapuanliike ja kyyditykset 1930, 451-452.

71 Uusi Suomi, 10 March 1929.

72 V. Tanner, Itsenäisen Suomen arkea. Valikoima puheita, Helsinki 1956 [1930], 309-310. 
among the Social Democrats to maintain that the government was ignoring the danger that the fascists were causing. ${ }^{73}$ The liberal press, in turn, viewed the movement as a threat to democracy and parliamentarism. ${ }^{74}$ In Sweden, conservative opinion tended to adopt an understanding view of the movement's anti-Communism, but the Social Democrats saw it as an alarming attack on democracy and no different in its basic character from fascist movements elsewhere in Europe. ${ }^{75}$ In a similar spirit, the leading liberal newspaper in Sweden used the expression 'half-fascist' when commenting on Finland during the Lapua Movement. ${ }^{76}$

The successful defence against the Lapua Movement did not by itself lead to a widely held opinion that Finland was an old democracy. A more important influence were the political developments in Germany. Although the Nazi takeover had gained some support both in Finland and in Sweden, as it was thought that it would defeat Communism and re-install a conservative regime, Nazi-sympathetic factions were expelled from the Conservative party in both countries in 1934 with the

\footnotetext{
73 Suomen Sosialidemokratti, 1 December 1929.

74 Helsingin Sanomat, 3 January 1930.

75 See H. Tingsten, The Debate on the Foreign Policy of Sweden, London 1949, 140, 149, 224; E. Lönnroth, Den svenska utrikespolitikens historia. V 1919-1939, Stockholm 1959, 129. 76 Dagens Nyheter, 6 August 1930.
} 
justification that fascism and Nazism were not national but foreign doctrines. ${ }^{77}$ This emphasis on the national political culture led to a more general acceptance of democracy among the Conservatives; and in this regard the rhetoric of Nordic democracy came to play a crucial role.

The Swedish political scientist Herbert Tingsten pointed out in his 1933 monograph on the breakthrough and subsequent crisis of democracy that the countries in which democratic methods had been applied for a longer period of time seemed to be able to defend democracy. ${ }^{78} \mathrm{~A}$ similar point was made in a major liberal Swedish newspaper in 1933, when it was held that democracy was in crisis, especially in countries where it had not had time to become rooted, such as Russia, Italy and Germany. ${ }^{79}$ Later in the same year, a Swedish Social Democratic MP argued that the course of events in Germany did not reveal much about democracy's capacities, because 'democracy had been out-manoeuvred in countries where it had never played a longstanding role' and that democracy had been tried in countries

77 See Torstendahl, Mellan nykonservatism och liberalism, 97, 103; Vares, 'Kokoomus ja demokratian kriisi', 16, 168-170, 201.

78 H. Tingsten, Demokratiens seger och kris. Vår egen tids historia 1880-1930. Den författningspolitiska utvecklingen 1880-1930, Stockholm 1933, 20, 32.

79 Dagens Nyheter, 30 July 1933. 
that did not have any democratic tradition. What was taking place, he explained, was that democracy had been pushed back to 'the oases where it had existed before: France, Belgium, Holland, Switzerland, England and the Nordic countries'. 80 While discussing the methods that a democracy was able to use against its internal enemies, he noted that the risk that the great majority of the people in the Nordic countries would turn against democracy was very marginal, as they had experienced the growth of popular self-government 'over centuries'. 'Even the Finnish people', he held, 'have recently shown an unexpected firmness in this matter' ${ }^{81}$ The rhetoric of Nordic democracy was based on the idea of a Nordic value community. The Swedish Prime Minister P.A. Hansson (Social Democrats) drew on references to a specific 'Nordic temperament', as he drew a contrast between young democracies and the Nordic countries; ${ }^{82}$ and the Finnish Prime Minister T. Kivimäki (Liberals) pointed to 'a similar world view' between Finland and the Scandinavian countries when he announced the Finnish foreign-policy orientation towards Scandinavia in 1935.83 Although viewed as being exceptional,

80 N. Andersson, $\ddot{A} r$ demokratin i fara i de demokratiska länderna?', in: Tiden 25 (1933), 484-488, 484 .

81 Ibid., 488.

82 Dagens Nyheter, 2 January 1935.

83 Valtiopäivät 1935. Pöytäkirjat III, Helsinki 1936, 2514. 
the Nordic value community was also often presented as a sign of a Western civilization. In Finland, this coupling of the Western and the Nordic values was used to criticise the Italian and German influences in Finland when the editor of a left-wing cultural weekly, Erkki Vala, demanded a Western cultural and political orientation in Finland in the name of the tradition of Nordic democracy. For Vala, the Nordic and Anglo-Saxon countries were the guardians of Western civilisation in the time of crisis. ${ }^{84}$ The association between Nordic and Western values also supported the idea that there was a family of countries that were old democracies. The Nordic Social Democratic parties made the notion of a specific Nordic democracy their own brand in 1935. This was demonstrated through 'The Day of the Nordic Democracy', a mass meeting organised against the fascist, Nazi and Bolshevik totalitarian doctrines. Besides the re-statement of longstanding Social Democratic political preferences such as those for social security and economic equality, and on some occasions socialism, this notion of an inherited democratic tradition was a crucial aspect of the branding of 'Nordic

84 Tulenkantajat, No. 3, 3 January 1933, and No. 5, 4 February 1933. See also Elmgren, Den allrakäraste fienden, 53-55, 103139. 
democracy'.85 According to the Finnish party leader Tanner, the peasant and the worker had always been free in the Nordic countries, whereas in the new democracies the ideas of freedom had not had time to become rooted and create a tradition strong enough to make democracy stable. ${ }^{86}$ Later in the same year at the meeting of the Nordic Social Democrats, he maintained that all the Nordic countries shared a strong tradition of democracy, which separated them from most of the other European countries. ${ }^{87}$ Significantly, he did not regard Finland as a new democracy, but an old Nordic one. The Conservatives viewed the Social Democrats' rhetoric of Nordic democracy as a party-political manoeuvre. For instance, one Swedish conservative paper claimed that the Social Democrats' appeal to democracy was 'empty and hollow'. ${ }^{88}$ The Conservative Party's daily in Finland held not only that 'the demonstration in Malmö was a brutal misuse of the word democracy for the purpose of party propaganda', but also that the socialism that was propagated aimed at the destruction of Nordic democracy and its ancient ideals of freedom'. ${ }^{89}$ However,

85 Fyra tal om nordisk demokrati, Stockholm 1935. For an analysis, see Kurunmäki, 'Nordic Democracy' in 1935', 37-43. 86 Ibid. $13,19$.

87 Suomen Sosialidemokraatti, 9 December 1935.

88 Sydsvenska Dagbladet, 26 August 1935.

89 Uusi Suomi, 29 August 1935. 
the non-socialists of different stripes found it difficult to reject the Social Democratic rhetoric of Nordic democracy, as the idea of a democratic tradition belonged in one form or another even to their view of what counted as a national tradition, as the rhetoric deployed by the Finnish conservative paper shows. In Sweden, the foremost Conservative advocate of the idea of an old Nordic tradition of democracy was Nils Herlitz, a Professor of Public Law, according to whom the consequences of the crisis of democracy did not need to be the same in the Nordic countries as in countries such as Portugal, Italy and Greece. In the Nordic countries, he held, individual freedom was respected and people had the principle of equality 'in their blood', as they were the inheritors of an ancient culture of rights and rule of law. ${ }^{90}$ In Finland, the prominent Conservative Paavo Virkkunen had argued, as early as 1927, that parliamentarism was democracy's highest form in order to dismiss the claims of dictatorial and antiparliamentarian doctrines. This unusual conservative defence of parliamentarism was based on the conviction that parliamentarism had the best chance to develop in countries

90 N. Herliz, Svensk självstyre, Stockholm 1933, 277-279. Herlitz presented his view of the democratic tradition and its contemporary virtues to an international audience in his prewar volume Sweden. A Modern Democracy on Ancient Foundations, Minneapolis 1939 . 
that had an ancient tradition of popular freedom, which included the Lutheran Nordic countries. ${ }^{91}$ Moreover, one of the most vocal intellectuals of the Pure-Finnish faction, the upcoming Agrarian politician Urho Kekkonen, who in his booklet Demokratian itsepuolustus (The Self-Defence of Democracy) (1934) had held that too much freedom was dangerous for democracy and that democracy needed to be able to fight also against its internal enemies, ${ }^{92}$ maintained that political and societal life in the Nordic countries had for centuries been based on democratic grounds. ${ }^{93}$

The celebration of the 500th anniversary of the Swedish parliament in 1935 provided an opportunity for Finnish politicians to emphasise the historical rootedness of democracy in a manner that transcended party allegiances. While PM Hansson held that the Swedish people had been able to maintain their ancient self-government', ${ }^{94}$ the Finnish delegation that was invited to the commemoration were able to

91 P. Virkkunen, 'Parlamentarismin pula nykyaikana. Suomen valtiollisen elämän kannalta', in: Valvoja-aika (1927), 287$313,292,298,307$.

92 U. Kekkonen, 'Demokratian itsepuolustus', in: U. Kekkonen, Puheita ja kirjoituksia IV, Helsinki 1973 [1934], 29-110. 93 Suomalainen Suomi (1935) 5, 236-239.

94 K. Hildebrand and E. Hallin (eds.), Riksdagens minnesfest 1935, Stockholm 1936, 68. 
underline Finland's adherence to the community of democratic Nordic countries by referring to the historical fact that political representation in Finland had been part of the old Swedish tradition. As such rhetoric indicates, it was thought possible to claim that there was a long constitutional tradition on which the present democracy was built. In the address congratulating the Swedish Riksdag, the Finnish parliament referred to 'the freedom and the spirit of togetherness in the Nordic democracies' when it maintained that these countries were strong enough to stand against the undemocratic changes of political representation that in many countries had destroyed the freedom of their citizens. ${ }^{95}$ The notion of Finland as an old democracy gained some international recognition in Karl Loewenstein's 1935 analysis of a Europe divided between autocracy and democracy. 96 The German legal scholar, who had emigrated to the USA two years earlier, and who would become known for his account of

95 Ibid., 132 .

96 K. Loewenstein, 'Autocracy versus Democracy in Contemporary Europe, I', in: The American Political Science Review 29 (1935) 4, 571-593; idem., 'Autocracy versus Democracy in Contemporary Europe, II', in: The American Political Science Review 29 (1935) 5, 755-784. 
'militant democracy' two years later, 97 held up the

Scandinavian countries as important examples of traditionally democratic countries that had been strong enough to stand against autocracy and dictatorship. Out of the countries that still had parliamentary rule intact, only Czechoslovakia did not own a democratic tradition. ${ }^{98}$ He held that '[i]n none of the countries now under a dictatorship has the tradition of self-government and of free institutions been sufficiently strong and lasting to avert the recurrence of autocratic rule, which, for an immemorial period, has been the customary form of national government' ${ }^{99}$

In his account, Finland was included among the Scandinavian countries, yet it was still a special case. According to Loewenstein, the dangers facing the democratic system had been greater in Finland than in the other Scandinavian countries.

97 K. Loewenstein, 'Militant Democracy and Fundamental Rights, I', in: The American Political Science Review 31 (1937) 3, 417-432; idem., 'Militant Democracy and Fundamental Rights, II', in: The American Political Science Review 31 (1937) 4, $638-658$

98 Loewenstein, 'Autocracy versus Democracy in Contemporary Europe, I', 571, 588.

99 Ibid., 586-587. 
For him, Finland was on 'a middle course'. ${ }^{100}$ Anticipating his subsequent development of the concept of militant democracy, he maintained that the restrictions that had been imposed on the Communists and the Lapua Movement in Finland were a good example of a country in which extremists from the left and the right were met with the strong resistance of the middle classes. ${ }^{101}$

\section{Concluding remarks}

This study has focused on the language of democracy in Finland and Sweden, but it may also allow for some general observations. First, the rhetoric of the youth and age of democracy should be understood as one way of contesting the meaning of democracy. Analysing this rhetoric may help us to understand the complexity of what was understood as democracy and the crisis thereof.102 Second, the ways in which certain

100 Loewenstein, 'Autocracy versus Democracy in Contemporary Europe, II', 763 .

101 Ibid.

102 For the contested concepts of democracy and crisis, see J. Gijsenbergh, 'Crisis of Democracy or Creative Reform? Dutch Debates on the Repression and Parliamentary Representatives and Political Parties, 1933-1940', in: J. Gijsenbergh et al. (eds.), Creative Crises of Democracy, Brussels 2012, 237-268; M. Llanque, 'The Edges of Democracy: German, British and 
political regimes were grouped together as survivors in the time of the crisis of democracy should not be understood merely as a result of an analysis of the contemporary situation, but also as a rhetorical means of defending democracy by emphasising its solid anchorage in the people and in the national tradition. The distinction between old and new democracies had an important role in this defence of democracy. In this regard, the rhetoric of Nordic democracy was in many ways similar to the wartime rhetoric of 'Western democracy' as promoted by British historians and politicians, anticipating the Wilsonian 1917 claim of making the world safe for democracy. 103 In both cases, many former opponents of democracy turned into democrats when they felt that their political system was threatened.

Third, the interwar defence of democracy made democracy in the more or less stable nation-states older than what any critical analysis of the historical formation of political institutions and previously used political language would suggest. We

American Debates on the Dictatorial Challenges to Democracy in the Interwar Years', in: Kurunmäki / Nevers / te Velde (eds.), Democracy in Modern Europe, 182-207.

103 See M. Llanque, 'The First World War and the Invention of 'Western Democracy'', in: R. Bavaj / M. Steber (eds.), Germany and 'the West'. The History of a Modern Concept, New York $2015,69-80$ 
should therefore understand assertions of the age of democracy as a result of a process whereby current political purposes motivated a rhetorical re-description of the past, to use Quentin Skinner's terminology.104 It is obvious that Finnish and Swedish political actors were not exceptional in this regard. For instance, Francis Dupuis-Déri has shown that the explicitly anti-democratic 'founding fathers' of the Canadian modern constitution in the $1860 \mathrm{~s}$ were reinterpreted as the creators of the Canadian democracy during the World War and the interwar period. ${ }^{105}$ One consequence of the retroactive invention of historical roots of democracy was that the 'breakthrough' of democracy in the form of the introduction of universal suffrage, and especially the role of women's suffrage, was made relatively insignificant as a historical landmark when the democracy that was to be defended was presented as an old democracy. ${ }^{106}$

104 See Q. Skinner, Visions of Politics. Volume I: Regarding Method, Cambridge 2002, 179.

105 F. Dupuis-Déri, 'History of the Word 'Democracy' in Canada and Québec: A Political Analysis of Rhetorical Strategies', in: World Political Science Review 6 (2010) 1, 1-23. 106 See J. Kurunmäki, 'How Women's Suffrage Was Devaluated: The Burden of Analytical Categories and the Conceptual History of Democracy', in: K. Palonen / J. M. Rosales (eds.), 
Finally, this study suggests that the historical existence of certain political institutions is important for the formation of 'an old democracy', as was correctly pointed out in the post-war research literature on democratisation; but it mattered less in terms of an actual continuity of predemocratic political institutions than as a source for a tradition of political rhetoric. A defence of democracy is likely to be more successful when there is a widely enough held opinion that democracy is a part of the national political culture. ${ }^{107}$ The sustainability and fragility of interwar democracy was concerned to a large extent with the question of how 'national' democracy was, and how this national character of democracy fitted into the framework of existing democratic institutions. In the case of Finland and Sweden, the geopolitical and ideological situation in Europe made most non-socialists take the side of existing political institutions instead of the anti-democratic doctrines that had been defined as anti-national. The leading Social Democrats, in turn, downplayed their internationalism and their initially reluctant attitude towards 'bourgeois democracy' in order to emphasise instead the national characteristics of democracy.

Parliamentarism and Democratic Theory: Historical and Contemporary Perspectives, Opladen et al. 2015, 31-52. 107 See also Loewenstein, 'Autocracy versus Democracy in Contemporary Europe, I', 587. 


\section{Abstract}

\section{Democracy both Young and Old: Finland and Sweden and the Interwar Crisis of Democracy}

It is often pointed out in the literature of democratisation and the breakdown of democracy that old democracies have been able to stand against the threat of totalitarian and extremist political doctrines better than young ones. This observation has usually been based on the existence of solid political institutions, certain class structures and the legitimacy of a political system. The focus of this article is on the rhetorical role that the division between 'old' and 'young' or 'new' democracies played during the interwar crisis of democracy. By focusing on the cases of Finland and Sweden, which have been described as a young democracy and an old democracy respectively in the literature on democratisation, the study directs attention to the ways in which the age of democracy has been produced in order to defend democratic institutions against totalitarian doctrines and practices. The article thus contributes to the conceptual history of democracy and helps explaining why Finland managed to maintain its democratic political institutions as one of the few new 
independent states that were born during and just after world War I.

Jussi Kurunmäki

University of Helsinki

Department of Cultures

P.O. Box 59 (Unioninkatu 38 A)

FIN-00014 University of Helsinki

jussi.kurunmäki@helsinki.fi 